\title{
Goa, India 2005
}

\author{
By Siraj Syed \\ Spring 2006 Issue of KINEMA
}

\section{INTERNATIONAL FILM FESTIVAL OF INDIA, GOA 2005}

At the inaugural function of International Film Festival of India 2005, on 24 November, there were some more high points and some lessons to be learnt. On the dark side were the disappointing audio-visual, the technical problems with digital sound, wrong cues and the length of the show itself. Sound played havoc for nearly half an hour, crackling and going silent in turns. Choice of the items and costumes ranged from the kathak dance, Mughal period style, to Bollywood item numbers of the $21^{\text {st }}$ century, to a rap-kathak fusion! On the bright side, octogenarian actor-director-producer Dev Anand, known for his now jaded romantic on-screen escapades with actresses one-fourth his age, gave a compact speech, without the stylised diction he is known for.

It was not easy getting a seat at the screenings held at the INOX multiplex cinemas, especially built at the old medical college campus by the Goa state government, but leased out to a multiplex chain. There were up to 150 persons seated on the carpet in some screenings. Opening film Olga (Brazil) lived up to expectations and was easily one of the best films on display. No wonder it had as many as six screenings!

There were other gems too. Stolen Eyes is about the process of targeting the minority community of Muslims in Bulgaria. Hundreds of thousands of Muslims were killed, converted, driven away or forced to assume a Christian identity. The film proves once again that highly political subjects can be very effectively filmed, without any slogan-mongering or big war scenes. At its level, Stolen Eyes does for its cause what films made by Steven Spielberg try to do with huge budgets and high drama.

Besides Stolen Eyes, among the ten best films seen at IFFI 2005 was Hayaat (which means Life in Persian and Urdu), one more magical masterpiece from Iran. Very rarely do IFFI audiences clap in the middle of a film. In Hayaat, they applauded at least three times before the end. There is so much attention paid to detail, casting is first class and performances first grade. Director Ghulam-Reza Ramzani is a director to watch out for. The kind of performances he has extracted from actors of ages from 9 months to 90 years is evidence that his background as theatre actor, writer and director has proven to be very useful. Hayaat is based on his own play, was made in 2004 and was part of the Retrospective on Iran at IFFI 2005.

Both Hayaat and Stolen Eyes have females as the main character. So do the films Olga, South, Hasina (an Indian gem), Manderlay, Looking for Angelina, Vera Drake, Don't Tell, Greenhouse Effect, La Pianiste, Manthan Ek Amrut Pyala, Am I Sexy? and many more. Tattoo, Summer Story and some other are about young boys. Iqbal is about a deaf and dumb young man. The heroine in South also has a physical problem. All these films were made in the last 2-4 years. Such a large output of films with these characters is clear indication that in recent times, more and more films are being made with women-oriented, children-oriented and handicapped person-oriented subjects.

Personal favourites at IFFI 2006 included Say Good Morning to Dad, Iron Island and Innocent Steps. Say Good Morning to Dad is from Bolivia and the subject is Che Guevara, the revolutionary who was killed in 1967 and later became a favourite of most revolutionaries in the world. In his first feature film, director Fernando Vargas Villagon uses the flashback technique, but in four different time zones: 1967, 1977, 1987 and 1997. A film that had possibilities of greatness falls just short of its goal.

Iron Island is one more proof that Iran is a treasure of talent in film-making. What an off-beat story! A man gives food and shelter to poor and homeless people on board an abandoned ship and rules them with an iron hand. Is he a crook or an angel? The character of Captain Nemat is a cross between Jules Verne's character from literature, Captain Nemo and the character from ancient mythology and Christian-Islamic history, Noah. Completely human characters, brilliant acting, masterly screenplay, direction and art (Mohammad Rasoulof) - no wonder it won several prizes, mainly in Hamburg and Montreal. It conquered IFFI too! 
One of the more entertaining films in the competition section came from South Korea, called Innocent Steps. Director and screenplay-writer Park Young-hoon starts the film in popular Hollywood style, with a lot of colour and glamour. But he goes on to prove that a film about fake marriages, dancing, jealousy and young lovers can be made with very little violence and no sexual content at all, and can still be interesting and sensitive.

I went to see Shadows of Time (Germany) with mixed feelings and came out with mixed reactions. It is a rare film, because it is made entirely with German finance. As many as 150 Indian crew-members and an entirely Indian cast worked in the film. It is directed by a German director of some international reputation, Florian Gallenberger, who has won an Oscar for his student film, I Want to Be (Quiero Ser) in 2001. His first feature film as writer director, Shadows of Time (Schatten der Zeit) is unique in some ways, but it is sad that the film falls a little bit short of expectations. Asterix and Obelix: Mission Cleopatra (Astérix 83 Obélix: Mission Cléopâtre, Alain Chabat, France, 2002) was an over-hyped disappointment.

It's time IFFI stopped the practice of promoting one commercial Hindi film. The last time, the Kisna: The Warrior Poet and director Subhash Ghai's promotion of his film were largely accepted because of the leading lady's live exotic rope dance performance. Sadly for the team, the film flopped when it was released some time afterwards. This year, the organisers gave us an overdose of a film called Holiday (by Pooja Bhatt). History repeated itself, and the film flopped, when released a couple of months later. Like the promotion of forthcoming Mumbai film industry releases, the Directorate of Film Festivals (DFF) needs to reconsider the whole idea of Bollywood premieres too. The chaos that prevailed and the maltreatment of senior journalists witnessed at the premiere of the star-studded Apharan was an insult to all film-lovers.

IFFI Goa ended on $4^{\text {th }}$ December 2005 and it is now pretty certain that IFFI 2006 will again be held in Goa. So, does the erstwhile 'travelling' film festival IFFI finally have a permanent venue? Only the DFF knows.

\section{References}

\section{AWARDS}

Awards (Competition restricted to Asian, African and Latin American films)

Golden Peacock and 100,000 Rupees fort he Best Film Iron Island by Mohammad Rasoulof (Iran)

Silver Peacock and INR 50,000 for the 'Most Promising Director' Vera Fogwill and Martin Desalvo (Argentina), for the film Kept $\&$ Dreamless

Silver Peacock and INR 50,000, 'Special Jury Award' Director Tom Hooper, for the film Red Dust (South Africa)

\section{Author Information}

Siraj SYED is a film-critic, actor and lecturer on cinema, who has been attending film festivals since 1976, and has so far covered 25 of them. He has been in the selection and organising committees of some of them. He has also sub-titled two IFFI festival films. Currently, he teaches cinema and mass media in Mumbai, India. 